\title{
Community Organizations and Local Governance in a Metropolitan Region
}

Jean-Marc Fontan

Université du Québec, Montréal, Canada

Pierre Hamel

Université de Montréal, Canada

Richard Morin

Université du Québec, Montréal, Canada

Eric Shragge

Concordia University, Canada

In a context of globalization, municipalities and metropolitan regions are involved in international competition to support economic growth. This leads to new forms of collaboration between public authorities and businesses, giving birth to new forms of urban and metropolitan governances. Moreover, many old neighborhoods of the central city and some districts of the old suburbs face growth in unemployment and poverty. In these local territories, community organizations put forward local development practices that aim to improve living conditions. These organizations cooperate with other community organizations, public institutions and private agencies. Thus, they are embedded in a kind of governance: a local governance. This article, based on the case of the metropolitan region of Montreal, highlights the conception of local development of these community organizations, the local governance in which they participate, and the link between this local governance with the urban and metropolitan ones.

Keywords: community organization; local development; governance; globalization; metropolis; Montreal

conomic transformation and neoliberal policies that go along with globalization have had, among other things, two important consequences for urban agglomerations in North America. First, municipalities and metropolitan regions increasingly compete within the international market,

Authors' Note: This article is based on a research project financed by the Social Sciences and Humanities Research Council of Canada. 
trying to attract investments, events, skilled workers, and so forth. To enhance the positioning of urban agglomerations, new forms of collaboration between public authorities and business have emerged, establishing urban and metropolitan governances targeting economic growth. Second, as a consequence of economic restructuring and related policies, unemployment and poverty have grown in many old neighborhoods of the central cities and in some districts of the old suburbs. In response, community organizations, intervening in different fields, are involved in local development practices that aim to improve local living conditions. To realize their mission, these organizations are linked to other community organizations, public institutions, and private bodies. These linkages shape multilevel networks that support collaborative relationships. These networks give birth to a kind of local governance that is concerned with socioeconomic problems on the local level within the metropolitan region. What does local development mean for community organizations? What sort of local governance do these organizations construct? What are their relationships with the state, and what is their degree of autonomy? Is there a link between the local governance in which community organizations play a key role and the urban and metropolitan governances mentioned above? These are the main questions to which we will respond in the context of the central city and the suburbs of the metropolitan area of Montreal, in Québec, Canada.

This article is divided into six parts. First, we present theoretical considerations about globalization, governance, and local development. Second, we comment on the tension between the community sector and the state in Quebec. Third, we describe some characteristics of the metropolitan region of Montreal, of the territories we have selected and of the organizations we have studied; we also explain our methodology. Fourth, we discuss the definitions of local development given by the community organizations we have studied. Fifth, we highlight the local governance structures and relationships through which community organizations contribute to local development. Sixth, we focus on the link between the socioeconomic development approach put forward by community organizations that play a key role in local governance and the pro-growth development strategies promoted by the institutions that formalize urban and metropolitan governances.

\section{Globalization, Governance, and Community Organizations}

Globalization and neoliberal policies have accelerated many changes in national economies as well as in modes of regulation. Internationally, the 
increased linkages of financial markets throughout the world have grown since the end of the Second World War. The economies of the industrialized countries have become more and more tertiarized, with the production of many goods transferred to developing countries to reduce the costs of workforce (Chenais 1994; Chalmin 1996; Berry, Conklin, and Ray 1997; Bauman 1998; Held et al. 1999; Beck 2000). Along with these changes, and particularly since the 1970s, the Keynesian mode of regulation has been challenged in order to increase the flexibility and the competitive advantages of national economies (Tickell and Peck 1995). Several factors, including the fiscal crisis of the state, demands and policies of supranational organizations and related agreements, and the economic competition on the international chessboard, have resulted in changes in roles and responsibilities of central governments. In the Canadian context, Brodie (2002) summarizes these changes as "continental integration and the ascendancy of neoliberalism as the dominant philosophy of governance-accompanied by the federal government's almost complete withdrawal from the social policy field ..." (p. 378). This reconfiguration opened the possibility for new modes of regulation, particularly in cities, and a passage from urban government to urban governance (Le Galès 1995; Pierre 1999; Jouve 2003). At the metropolitan level, the competition between urban agglomerations motivates representatives of municipalities and private corporations to work together to elaborate and implement development strategies, putting in place what we can refer to metropolitan governance.

With these forms of governance, central governments have redefined their roles from direct intervention to steering society to reach collective goals (Pierre and Peters 2001). Definitions of governance emphasize different components within it. For example, Pierre (2005) defines it as "the process and mechanisms through which significant and resource-full actors coordinate their actions and resources in the pursuit of collectively defined objectives" (p. 452). Andrew and Phillips (2002) state that urban governance implies a shift from hierarchy to horizontality and that it relies on interdependence among the public, the private, and the voluntary sectors. Furthermore, achieving policy goals is dependent on collaboration among multiple players whose interests and responsibilities intersect in a fluid and contingent way. This last aspect is important, because it implies that governance can be understood as relationships that are in flux, that are not stagnant, and do not necessarily rely exclusively on permanent, externally defined structures.

Local development through community organizations is another response to the economic and social restructuring described. In metropolitan regions, the decline of the manufacturing sector, the requirement for more 
flexibility, and cutbacks in welfare programs particularly affect people living in some core neighborhoods and some old suburban districts. Consequently, there is a growing incidence of socioeconomic exclusion and poverty. Metropolitan territories become more and more fragmented (Mollenkopf and Castells 1991; Klein, Fontan, and Tremblay 1999). Community organizations have become key actors in responding to the social and economic deterioration of low-income neighborhoods. In these districts, where there is a concentration of the poor and unemployed people, these organizations of the civil society are involved in local development practices (Clavel, Pitt, and Yin 1997; Moulaert, Delvainquière, and Delladetsima 1997). Local development can be defined as a strategy that aims to change the economic, social, cultural, environmental, and political situation in order to improve living conditions in a local territory, by mobilizing internal and external actors and resources (Organisation for Economic Co-Operation and Development 1999; Pecqueur 2000; Vachon 1993; Stöhr 2003). Thus, the definition of local development does not only include an economic dimension but also integrates other aspects related to living conditions. It also emphasizes the process of development that implies the autonomy and participation of individual and collective local actors. And it is not "localist," because external actors and resources are involved. This definition of local development is closer to the European conception of local development than to the American one that highlights the economic aspect and that is often called "local economic development" (Blakely and Bradshaw 2002).

Local organizations are involved in mobilizing resources from inside and outside the local territory to provide services related to everyday lives and ways to create and/or to get jobs. At the same time, with governments' shift to neoliberalism and related social policies, local organizations have picked up increased responsibilities for social provision and economic development; however, more senior levels of government are actively involved in shaping these practices. (Ilcan and Basok, 2004; Gough, Eisenschitz, and McCulloch 2006) There is a movement in two directions: community organizations act from the bottom-up, initiating services and programs, while governments view "community as policy," organizing intervention, and funding programs that shape local activity as responsible for a variety of services and programs. This vertical relation, then, has resulted in an increasingly collaborative relationship between community and government, with diminished conflict (Fisher and Shragge 2000, 2007; Hamel, Lustager-Thaler, and Mayer 2000). To provide effective services and programs and to overcome limited local resources, there is a horizontal collaboration between community organizations, creating relationships 
of negotiation and cooperation with each other, in addition to the different tiers of government and some private foundations to obtain resources, to initiate interventions, and to coordinate actions. These processes of collaboration between different actors preoccupied by social and economic development of local territories inside metropolitan regions constitute forms of local governance, in which civil society through community organizations plays an important role (Friedmann 1998). Pierre and Peters (2001) use the term communitarian governance to describe the role of local voluntary organizations in a consensual process of organizing governance without government. The emphasis is on the important role of local organizations playing a role in the governance process, but their participation is structured by government at the same time. Ilcan and Basok (2004) describe this as "governing through community under advanced liberalism" and argue that "community government refers to the ways in which the contemporary politics of government has come to define, shape, and orient communities ... such that they engage in activities that attempt to responsibilize certain groups of citizens for particular purposes and ends" (p. 130). Community organizations in their participation in local governance cannot be separated from their role as service providers, as the state has shifted many responsibilities to voluntary providers. Hamel and Jouve (2006) make this point in relation to the changes in Québec, arguing that governance has served as an ideological framework whose goal is to justify and legitimate the passage from a Keynesian to a neoliberal system of social and economic organization. Thus, local governance can be understood as a flexible process that brings local actors with different interests to participate in local decisions but at the same time is linked to the transformation of the role and responsibilities of higher levels of government - the provincial and federal in the Canadian context-with augmented responsibility for local communities through municipalities and community organizations. Therefore, the local governance in which community organizations participate is "local," because local territory is the object of this governance but is also a multilevel governance in which the actors involved-especially the different tiers of government-are present at the inframunicipal, municipal, and supramunicipal levels.

Since the 1990s, urban governance has been increasingly open to the active participation of social actors from within civil society. Nonetheless, this involvement has not been sufficient to produce a stable institutional order. In comparison with the situation in the United States, Canadian institutional reforms of urban and metropolitan governance came about through a more formal and traditional route. Provincial governments imposed a 
drastic solution on municipalities and local governments to problems of central city financing infrastructures and services by amalgamating the number of municipalities in a given metropolitan area to create mega-cities (Sancton 2001). This solution was described and even denounced by many as technocratic and antidemocratic (Sancton 2000). Borrowing its methods from the old regionalist approach, this solution differed from the new regionalist philosophy counting on cooperation. But its success was not as planned. In other words, it did not achieve what was targeted by the reformers. In fact, the planners and the elected people who managed those reforms were surprised to observe that citizens were not seduced at all by technocratic solutions to problems of urban and metropolitan governance. Moreover, the citizens did not hesitate to mobilize against the reformist project of the state, demonstrating a strong sense of belonging to their older municipalities and their local governments (Boudreau 2003; Hamel 2006). Thus, metropolitan governance has to face difficult choices. On one hand, authoritarian and technocratic solutions are rejected by citizens. On the other hand, more adaptive solutions such as the ones suggested by new regionalists are not effective. By counting on cooperation, the new regionalist approach is not able to counter the strong reality of the market. In this context, who is going to speak for the public? To what extent are community organizations able to suggest new solutions to the problems of urban and metropolitan governance that neither new nor old regionalists can solve? Could these organizations be able to mediate-better than the state- the involvement of citizens?

In this article, we suggest that community organizations are involved to some extent in the multigovernance process. As Eme (2007) emphasized, in urban territories, state regulation is fragmented into domains of intervention. Consequently, governance, which corresponds to the participation of other actors in this regulation, is also fragmented. Eme used the French term of polygouvernance to evoke this phenomenon. Community organizations are involved in this multigovernance process through engaging in relations with other community organizations as they fulfill their mission. They also have relations with public agencies at the infralocal level and at supralocal level when delivering their services to their constituencies. However, these public agencies are specialized agencies in domains such as employment, social affairs, education, culture, leisure, and so forth. That is, the types of governance they are dealing with are mainly specialized within the management of a specific social domain. In this sense, they do not interfere-at least not significantly — with economic issues and the management of urban and metropolitan development. Pierre (1999) qualifies the absence 
of articulation between one type of governance with another type as a "governance gap $(\ldots)$ caused by the organizational insufficiency and lack of inter-organizational coordination" (p. 390). We point out that there is a governance gap between the local governance orientated toward the improvement of living conditions in which community organizations participate and that of municipal and metropolitan governances focusing on economic growth in which these organizations are excluded.

\section{Community Organizations and the State}

To understand the ability of community organizations to represent themselves beyond the local level, it is important to understand that these organizations in Quebec are highly organized and, through many years, have established coalitions of organizations at the local, regional, and provincial levels that have initially fought for recognition from the government as well as policies and criteria for funding them. Most of the public institutions that have relations with the community organizations we have studied belong to the provincial government. They mainly provide financial resources to these organizations. The provincial government of Quebec is responsible for domains such as education, social affairs, welfare, and employment that are related to the intervention of a large proportion of community organizations. Moreover, this government has also created a body in charge of community action. By the 1990s, the relationship with the government moved to a new stage of recognized partnership. Until its defeat in 2003, the Parti Québecois government had initiated a policy in which the "community sector" was to receive greater recognition and systematic support. Under the Secretariat de l'Action Communautaire Autonome [Secretary for Autonomous Community Action], and a related interministerial committee, policy for the community sector was to be decided. This sector itself was represented by a Comité Aviseur de l'Action Communautaire Autonome [Advisory Committee for Autonomous Community Action]. This committee was composed of representatives of 20 domains of intervention and more than 130 provincial, regional, and local coalitions or "regroupements." These structures demonstrate the way that the community sector has influenced state policy and is simultaneously shaped by it. The formalization of representation allows organizations to defend their self-interest and influence policy on funding and conditions for it.

The nature of the relationship between community organizations and the provincial government has been studied in the 1970s and the 1980s (McGraw 
1978; Deslauriers 1985; Fincher and Ruddick, 1983), but the structuring of these relationships has evolved and become formalized, and the consequences are now debated. Deslauriers and Paquet (2003) discuss two positions in this regard. The first is that greater recognition by the state (institutionalization) is what organizations have been seeking and it represents a gain in the status and role of the community sector. In contrast, the other position argues that these processes have been imposed by the state and this limits autonomy and democracy. Similarly, Parazelli and Tardif (1998) contrast what they describe as autonomous community action based on people in a community defining their own needs, strategies and priorities, with communautique, a French word derived from communautaire [community] and technocratique [technocratic], in which the community sector becomes linked to the technocratic apparatus of the state. As a consequence of this communautique, community organizations turn out to be subsystems of institutional intervention, thus becoming subcontractors of the state dealing with fragmented social problems. Polarizing these positions is useful, as it frames the debate. For other authors, the reality, however, is far more complex. White (1997) has described communautique as "contradictory participation" and Panet-Raymond and Mayer (1997) as "critical co-operation or co-operative conflict." It is important to acknowledge that the relationships of conflict and collaboration coexist, particularly within the current context in which both the state and the community sector have an interest in strengthening local organizations. How much autonomy remains for the community sector to build participatory and enlarged democratic practices and to challenge the social policy and other transformations that have exacerbated poverty and inequality in Montreal and its suburbs remains an open and ongoing tension that shapes both local work and local governance.

\section{The Case of Montreal}

In $2001,{ }^{1}$ the population of Canada was approximately 30 million. There were 7.2 million inhabitants in the province of Quebec, and the metropolitan region of Montreal had 3.5 million residents. The City of Montreal that covers the largest portion of the island of Montreal is the most important municipality of this region, with 1.5 million inhabitants. This city has the highest poverty rate of the most important Canadian cities.

In 2001, 29\% of the people living in the city of Montreal were under the low-income line calculated by Statistics Canada, compared to $15 \%$ in Ottawa, $22.6 \%$ in Toronto, $20.2 \%$ in Winnipeg, $14.1 \%$ in Calgary, and $27 \%$ in Vancouver (Conférence Régionale des élus de Montréal 2004). The percentage 
of people living under the low-income line in Montreal is greater than that of the metropolitan region, which is $22 \%$, because generally, there is less poverty in the suburbs than in the central city. Nevertheless, some suburban districts $^{2}$ and boroughs ${ }^{3}$ of the metropolitan region of Montreal have percentages of people who are under the low-income line higher than the regional average. It is the case of two districts of Laval, a suburb of the north shore: Pont-Viau (25\%) and Chomedey (24\%). It is also the situation of a borough of the City of Longueuil, a suburb of the south shore: Vieux-Longueuil $(25.2 \%)$. However, some districts and boroughs of the central city have percentages of people living under the low-income line much higher than the regional average (e.g., the district of Côte-des-Neiges [40.8\%] and the borough of Verdun [31.7\%]).

For the purpose of our research, we studied these territories within the metropolitan region of Montreal we have just mentioned: the City of Laval (340,000 inhabitants) and the borough of Vieux-Longueuil (128,000 residents), both suburbs; and the district of Côte-des-Neiges (100,000 inhabitants) and the borough of Verdun ${ }^{4}(60,000$ residents) in the central city. In each of these four localities, the poverty rate, as we have already mentioned, is high. We have chosen four community organizations in each territory, each one working in one of the following four domains:

- coordination and mobilization of local organizations (community council);

- social, cultural, and leisure services to community (community center);

- animation and help provided to young people (youth organization);

- support for employment (employment organization).

We have selected these four domains because they were the ones present in each of our four locations. Thus, we studied 16 community organizations in four locations and four sectors of intervention. The main characteristics of these organizations are presented in Table 1.

After having consulted documents produced by these organizations, such as annual reports and action plans, we interviewed the key actors of these organizations-the director-coordinator and the president of the board of directors. In two cases, we only met the director-coordinator or the president. Therefore, we talked with 30 people involved in these community organizations, of which 25 were women. This reflects the importance of the presence of women in community organizations, which is a sign of the move to a service orientation that has taken place since the 1980s in a context of the downsizing of the state (Lamoureux 1998). We have also conducted interviews with about 40 representatives of the main public and 


\section{Table 1}

\section{Characteristics of the Community Organizations Studied in the Metropolitan Region of Montreal}

\begin{tabular}{|c|c|c|c|c|}
\hline $\begin{array}{l}\text { Territory and } \\
\text { Organization }\end{array}$ & $\begin{array}{c}\text { Year of } \\
\text { Foundation }\end{array}$ & $\begin{array}{l}\text { Annual Budget } \\
\text { (2001-2002), } \\
\text { in Canadian } \\
\text { Dollars }\end{array}$ & $\begin{array}{l}\text { Number of } \\
\text { Employees }\end{array}$ & Mission \\
\hline \multicolumn{5}{|l|}{ Laval } \\
\hline $\begin{array}{l}\text { Corporation de } \\
\text { Développement } \\
\text { Communautaire de } \\
\text { Laval (community } \\
\text { council) }\end{array}$ & 1995 & 221,200 & $\begin{array}{l}4 \text { full-time } \\
1 \text { part-time }\end{array}$ & $\begin{array}{l}\text { Securing the active par- } \\
\text { ticipation of the com } \\
\text { munity organizations } \\
\text { to the socioeconomic } \\
\text { development }\end{array}$ \\
\hline $\begin{array}{l}\text { Centre Communautaire } \\
\text { Val-Martin (commu- } \\
\text { nity center) }\end{array}$ & 1991 & $1,000,000$ & $\begin{array}{l}17 \text { full-time } \\
50 \text { part-time }\end{array}$ & $\begin{array}{l}\text { Improving individual, } \\
\text { social, and economic } \\
\text { lives of the population }\end{array}$ \\
\hline $\begin{array}{l}\text { Maison des Jeunes, } \\
\text { Ste-Dorothée (youth } \\
\text { organization) }\end{array}$ & 1994 & 66,500 & 4 full-time & $\begin{array}{l}\text { Being a locus of meet- } \\
\text { ing, animation, and } \\
\text { aid for youth }\end{array}$ \\
\hline $\begin{array}{l}\text { Centre Régional de } \\
\text { Récupération et de } \\
\text { Recyclage de Laval } \\
\text { (employment organi- } \\
\text { zation) }\end{array}$ & 1998 & 821,000 & 9 full-time & $\begin{array}{l}\text { Contributing to individ- } \\
\text { ual, social, and } \\
\text { economic integration }\end{array}$ \\
\hline $\begin{array}{l}\text { Longueuil } \\
\text { Corporation de } \\
\text { Développement } \\
\text { Communautaire de } \\
\text { Longueuil (commu- }\end{array}$ & 1989 & 328,185 & $\begin{array}{l}5 \text { full-time } \\
3 \text { part-time }\end{array}$ & $\begin{array}{l}\text { Initiating to and } \\
\text { supporting commu- } \\
\text { nity development }\end{array}$ \\
\hline $\begin{array}{l}\text { nity council) } \\
\text { Centre Communautaire } \\
\text { le Trait d'Union }\end{array}$ & 1983 & 475,331 & $\begin{array}{l}9 \text { full-time } \\
30 \text { part-time }\end{array}$ & $\begin{array}{l}\text { Providing community, } \\
\text { leisure, sociocultural, } \\
\text { and pastoral services }\end{array}$ \\
\hline $\begin{array}{l}\text { (community center) } \\
\text { Carrefour-Jeunesse }\end{array}$ & 1983 & 900,000 & 35 full-time & $\begin{array}{l}\text { Helping teenagers and } \\
\text { youth who face }\end{array}$ \\
\hline $\begin{array}{l}\text { Longueuil, Rive-Sud } \\
\text { (youth organization) } \\
\text { Projet Local d'Aide à la } \\
\text { Création d'Emploi, } \\
\text { Rive-Sud (employ- } \\
\text { ment organization) }\end{array}$ & 1984 & N/A & 45 full-time & $\begin{array}{l}\text { difficulties } \\
\text { Working on the } \\
\text { improvement of } \\
\text { living conditions of } \\
\text { the unemployed }\end{array}$ \\
\hline $\begin{array}{l}\text { Côte-des-Neiges } \\
\text { Conseil Communautaire } \\
\text { de Côte-des-Neiges } \\
\text { (community council) }\end{array}$ & 1987 & 942,241 & 1.5 full-time & $\begin{array}{l}\text { Supporting the coordina- } \\
\text { tion and collaboration } \\
\text { of local organizations } \\
\text { Developing community } \\
\text { life, fighting against }\end{array}$ \\
\hline $\begin{array}{l}\text { Centre des Loisirs de } \\
\text { CDN (community } \\
\text { center) }\end{array}$ & & & & $\begin{array}{l}\text { loneliness, promoting } \\
\text { social integration }\end{array}$ \\
\hline $\begin{array}{l}\text { Maison des Jeunes de } \\
\text { Côte-des-Neiges } \\
\text { (youth organization) }\end{array}$ & 1983 & N/A & 6 full-time & $\begin{array}{l}\text { Offering leisure } \\
\text { activities and } \\
\text { support to youth }\end{array}$ \\
\hline
\end{tabular}


Table 1 (continued)

\begin{tabular}{|c|c|c|c|c|}
\hline $\begin{array}{l}\text { Territory and } \\
\text { Organization }\end{array}$ & $\begin{array}{l}\text { Year of } \\
\text { Foundation }\end{array}$ & $\begin{array}{l}\text { Annual Budget } \\
\text { (2001-2002), } \\
\text { in Canadian } \\
\text { Dollars }\end{array}$ & $\begin{array}{l}\text { Number of } \\
\text { Employees }\end{array}$ & Mission \\
\hline $\begin{array}{l}\text { Petites-Mains (employ- } \\
\text { ment organization) }\end{array}$ & 1994 & 660,680 & 13 full-time & $\begin{array}{l}\text { Working on the } \\
\text { improvement of the } \\
\text { living conditions of } \\
\text { the unemployed }\end{array}$ \\
\hline \multicolumn{5}{|l|}{ Verdun } \\
\hline $\begin{array}{l}\text { Conseil Verdunois } \\
\text { d'Initiative et } \\
\text { d'Intervention } \\
\text { Communautaire } \\
\text { (community council) }\end{array}$ & 1990 & 500 & None & $\begin{array}{l}\text { Supporting the co ordina- } \\
\text { tion of local organi- } \\
\text { zations and defending } \\
\text { their interests }\end{array}$ \\
\hline $\begin{array}{l}\text { Centre Communautaire } \\
\text { Dawson (community } \\
\text { center) }\end{array}$ & 1959 & 550,000 & 8 full-time & $\begin{array}{l}\text { Contributing to the } \\
\text { improvement in the } \\
\text { quality of lives of } \\
\text { English-speaking } \\
\text { people }\end{array}$ \\
\hline $\begin{array}{l}\text { Toujours Ensemble } \\
\text { (youth organization) }\end{array}$ & 1979 & N/A & 12 full-time & $\begin{array}{l}\text { Providing help to youth } \\
\text { facing difficulties }\end{array}$ \\
\hline $\begin{array}{l}\text { Services d'Intégration } \\
\text { Professionnelle- } \\
\text { Carrefour Jeunesse- } \\
\text { Emploi de Verdun } \\
\text { (employment organi- } \\
\text { zation) }\end{array}$ & 1978 & N/A & 12 full-time & $\begin{array}{l}\text { Contributing to the } \\
\text { socio-professional } \\
\text { integration of youth }\end{array}$ \\
\hline
\end{tabular}

charitable institutions, with which the community organizations we have studied are linked. Finally, we have analyzed documents published by institutions that formalized different public-private partnerships representing various forms of municipal and metropolitan governance.

\section{Community Organizations and Local Development}

According to their leaders, the community organizations, in the four domains of intervention and in the four localities we have selected, contribute to local development. Indeed, most of the individuals consider that their community organization is a local development organization. Nevertheless, they put forward numerous definitions of local development, which we summarize as follows: 
- a response to local needs, including the creation of local jobs;

- the social and economic development of the community, the improvement of living conditions of local people, and the development of neighborhood life and identification with their locality;

- working with people, citizens' participation, supporting initiatives of the local population, and the mobilization local organizations;

- the development of self-respect, of personal autonomy, and of a sense of responsibility.

Thus, local development covers many aspects. The first definition focuses on collective needs: response to social demands and creation of local jobs. The second one underscores objectives related to the community: social and economic development of the community and improving neighborhood life. The third one emphasizes the process of development: citizens' participation and mobilization of local organizations. The last one highlights individual empowerment: self-respect, personal autonomy, and sense of responsibility. These conceptions of local development correspond to the definition we have presented earlier, one that not only focuses on the economic dimension of local development but one that also emphasizes the process of development, pointing out the autonomy and the participation of individual and collective actors. However, the mobilization of external actors and resources is not explicitly mentioned, but in fact, these organizations are in touch with external actors and receive external resources (mainly financial). Moreover, the environmental aspect of development is not also explicitly mentioned, but one of the employment organizations we have studied intervenes in recycling garbage.

We observe relationships between the conception of local development and the community organizations' domain of intervention. The individual actors involved in community councils tend to define local development as related to objectives of the wider community (3/8) and with the development process (4/8). This is congruent with the mission of these organizations. The individuals involved in community centers gave two main definitions of local development: a response to collective needs (3/7) and the development process (3/7). These definitions also match with the objectives of these organizations. The individuals involved in youth community organizations do not refer to objectives related to the wider community, targeting a more specific population. Therefore, it is not surprising that two representatives of these organizations give a definition of local development, associating it with individual empowerment. Finally, the individual actors from the employment organizations define local development in 
terms of collective needs (2/7), objectives related to community (3/7), and development process (2/7), but not with individual empowerment (which is surprising, considering that these organizations also target a specific group-the unemployed). Nevertheless, their contribution to social change is mainly perceived in relation with the empowerment of specific groups.

\section{Community Organizations and Local Governance}

To contribute to local development, the community organizations we have studied are in touch with other community organizations, public institutions, and private bodies that are both inside and outside their local territory. The other community organizations and the public institutions that they are linked with intervene on the inframunicipal level, the municipal level, and the supramunicipal level. The private bodies work on a supramunicipal basis. Thus, even if they are locally rooted, the community-based organizations that we have studied do not limit their relationships to that scale of action. As Clavel, Pitt, and Yin (1997) have written about community development corporations in the United States, we also can emphasize that these community-based organizations are not exclusively "localist," given their multilevel networks. However, the primary goal of these external relationships is in relation to securing funding and other support for their local activities.

\section{Collaboration With Different Actors}

Community organizations relate to different bodies for a variety of purposes. One important connection of the organizations that we studied is with coalitions that bring together organizations on a territorial basis (the neighborhood, the borough, the municipality, the region) or on a sectoral basis (local coalitions, community center, employment, youth). These organizations are usually the locus for sharing problems and issues and for coordination of actions and for demands to government (usually provincial) in order to get more resources or to modify policies and programs. Some local organizations, such as the community economic development corporations, also provide financial resources to community-based organizations, playing an intermediary role between the state and the community. Finally, the main private body to which community organizations are linked is Centraide (United Way). This charitable institution receives donations from people and gives financial support to many community organizations on a regional 
basis. There are also some private foundations that were created recently, which finance community organizations. These foundations intervene throughout the province. Other public institutions connected with community organizations are related to the municipal administration and to school boards. They supply material resources to community organizations and implement projects in partnership with them. Some federal government agencies also give financial help to the community organizations.

\section{Collaboration At Different Scales}

The scale of the relationships between the community organizations and their institutional network depends mainly on the purpose of these linkages. We have distinguished three purposes: to get financial resources, to share concerns and to make claims, and to implement projects based on partnership.

The networks developed by community organizations to get financial resources appear to be mainly supramunicipal: public agencies related to the provincial government and private bodies are the key institutions of these networks in each location we have studied. In fact, it is the provincial government that gives to community organizations the most important portion of its financial resources.

The networks put in place to share concerns among community organizations or to make claims (usually to government) are mainly inframunicipal and municipal in Verdun and Côte-des-Neiges - a borough and a district of the City of Montreal, respectively - and they cross the three levels (inframunicipal, municipal, and supramunicipal) in the suburbs of Laval and Longueuil. In these two suburbs, half of the community organizations that we have studied provide their services on a municipal or supramunicipal basis; and their networks are composed of community organizations, public institutions (both provincial and municipal), and private bodies. Last, the networks developed in order to implement projects based on partnership are inframunicipal in Verdun; inframunicipal and municipal in Côtedes-Neiges; and inframunicipal, municipal, and a bit supramunicipal in Laval and Longueuil. These networks mainly include public institutions (both provincial and municipal), school boards, and community organizations.

\section{Collaboration With Negotiations}

The networks in which community organizations are embedded constitute spaces of negotiations where concerns, resources, and projects are discussed and put forward. Our results suggest that the collaboration between 
the community organizations that we have studied and other community organizations to share concerns, to coordinate actions, and to make claims is usually harmonious. The collaboration between community organizations and municipal services and school boards to implement projects in partnership also appears to be quite harmonious. However, the collaboration between community organizations and public agencies belonging to the provincial government seems to be less so. As we have highlighted, this collaboration raises the question of financial resources and policies that shapes their allocation, and this question is a key one. Most of the subsidies are tied with particular programs and specific activities defined by government. Consequently, the autonomy of the community organizations is constantly threatened and the leaders of these organizations negotiate with provincial public authorities in order to gain a sufficient margin of maneuver. Those who represent employment organizations appear to feel the most constrained in their action. These organizations receive their financial support from governmental programs that have their own objectives linked to workfare. These last objectives are not necessarily shared by these community organizations.

Thus, local governance, which refers to the collaboration of different actors involved in local development, is a multilevel one that is not exempt from tension. Governance can be understood as a process of negotiation and interaction between organizations and not only as formal participatory structures. It concerns steering and coordination, particularly related to the allocation of resources rather than on direct decision making by a centralized body (Pierre and Peters 2001). As European sociologists Jean Remy (1998) and Maurice Blanc (1998) have written, this local governance, as well as the other types of governance, implies social transactions between organizations that do not necessarily share the same interest and the same resources. These transactions produce compromises. This is particularly true regarding the relationships between community organizations and public institutions. However, the compromises are not only one-way. Indeed, interviews with individual actors working in public agencies, except those related to the Ministry of Employment, reveal that their programs or their way to manage them can be influenced by community organizations. As Bob Jessop (2001) has mentioned, if action is structured by the institutional context, the institutional context is also structured by action. The institutionalization of community organizations, which is reinforced by their networks and by their involvement in local governance, affects both these organizations and the public institutions. 


\section{Local Governance Versus Urban and Metropolitan Governance}

The community organizations that we have studied are at the heart of a specific type of local governance that aims to bring some socioeconomic change at the local level. Community councils associate these changes locally through mobilization, coordination, democracy, and neighborhood improvement. These collective issues are related to the mission of these organizations, which, as we have just emphasized, intervene with the collaboration of many other actors, from the community sector as well as from the public and private sectors.

For the other organizations such as community centers, youth organizations, and employment organizations, changes are related to activities provided to individuals affected by poverty and personal issues such as the development of self-confidence and individual potential among immigrant women, support to individuals for them to go back to school or to work, and aid to individuals who are facing social problems. Thus, this last conception of social change corresponds to individual integration in society and social cohesion, which is congruent with a service approach. This conception reflects the pragmatism of urban movements (Hamel, Lustager-Thaler, and Mayer 2000) and the importance given to individual autonomy in a context of advanced modernity and globalization (Beck 2000). The objective is not to change the society but to help individuals that are marginalized from the spheres of consumption and production to be part of the society and to benefit from it.

Community organizations and their partners in this kind of local governance focus on the local and socioeconomic changes and put forward a development approach that appears to be defensive (Castells 1999), with their concentrating on problems solving. In contrast, other actors, associated with the market and the state, are working in partnership, in order to adapt their city and the metropolitan region to globalization. The development approach that these actors of urban and metropolitan governances promote is offensive (Leborgne and Lipietz 1992): the main objective is to take advantage of globalization through a growth strategy. This public-private partnership gives birth to another form of governance in which community organizations are excluded.

In the region of Montreal, metropolitan governance is institutionalized through the Communauté Métropolitaine de Montréal (CMM) [Montreal Metropolitan Community], created officially in 2000 but put in place in 2002 , which brings together the 82 municipalities of the region and is 
responsible for Montreal International, a public-private organization with the mandate to promote the metropolis within the international marketplace. The CMM's economic plan published in 2005 and titled Charting our International Future: A Competitive Metropolitan Montreal Region points out the targeted goal:

Our goal is clear: Montreal must become one the most competitive metropolitan area in North America. To accomplish this, the CMM has articulated a fourfold strategy: Montreal must become a learning region, competitive and prosperous, attractive and world-class. And the way to achieve this is through knowledge, productivity and innovation, attractiveness and foreign direct investment. (p. 5)

In the municipality of Montreal, the urban governance of economic matters is structured through a partnership between the city, the other tiers of government, and businesses. The last economic development plan of the City of Montreal, titled Success@Montreal, also published in 2005, refers to this partnership. In the version of this plan submitted to consultation in 2004, the positioning of the city was as follows:

Montreal is a global city, one of the most interconnected in the world. It is also renowned for its role in different global networks, including world-class sporting events such as the Olympic Games and the Formula 1 circuit. Montreal is also part of the network of cities with a focus on the arts and digital creation, great festival cities, and a city that hosts major international organization. (City of Montreal 2004, p. 5)

Moreover, the municipality has put in place an Economic Orientation Committee with 25 members: seventeen come from the business, five from colleges and universities, and three from paramunicipal societies.

In the City of Laval, urban economic governance is formalized into Laval Technopole. The board of directors of this agency is composed of 17 representatives from private enterprises, two city councilors, the director of a university research center, and the general director of this body. Its mandate is as follows:

to develop the Laval economy by attracting investment and companies to its territory and by supporting resident companies in its three sectors of excellence: the BIOPOLE, the e-POLE and the AGROPOLE. The agency is also responsible for developing the City of Biotechnology and Human Health of Metropolitan Montreal, the Laval Science and High Technology Park and Laval's municipal industrial parks. (Laval Technopole 2005) 
Finally, in the City of Longueuil where the borough of Vieux-Longueuil is located, urban economic governance is institutionalized into a body called Longueuil Economic Development. The board of directors of this agency is composed of 11 representatives from private enterprises- 2 from the municipality (the mayor and a city councilor), 2 from colleges and universities, 1 from a parapublic institution, 1 from an association of agricultural producers located in this city, and the general director of this body. This agency's mission is "to increase collective wealth and strengthen Longueuil's role and economic significance in the Greater Montreal area by maintaining, developing and attracting businesses and creating quality employment" (Longueuil Economic Development 2005).

These forms of urban and metropolitan governance do not seem to be concerned with poverty and social inequalities on their territory. Their mission is primarily to attract investments. The actors involved in these are not the same as those who participate in the local governance: the public institutions and the private representatives are different and community organizations are limited only to the local. There is no articulation between urban and metropolitan strategies for economic growth and local development approaches for the improvement of living conditions of poor people. This corresponds to a "governance gap" (Pierre 1999), a gap between two kinds of governance in the process of multigovernance. This can also be associated with the lack of linkage between community economic development practices and metropolitan development strategies that we have highlighted in a previous research concerning Montreal, Toronto, Boston, and Pittsburgh (Morin and Hanley 2004).

\section{Concluding Remarks}

In the context of globalization, where metropolitan areas play an important role, local development strategy aims to change the economic, social, cultural, political, and environmental situation in order to improve living conditions at the inframetropolitan level, by mobilizing local and external actors and resources. As we have seen in the case of the metropolitan region of Montreal, community organizations play a key role in local development strategies. We have studied organizations involved in four domains: local coalitions, community centers, employment, and youth. Such organizations are present not only in the central city but also in the suburbs. They intervene principally in the neighborhood and in the borough, but some of them, particularly in the suburbs, also provide their services on municipal and 
supramunicipal scales, the contours of the "local territory" being variable. The results of our research suggest the following answers to the four questions we have raised in the introduction of this article.

\section{What Does Local Development Mean for Community Organizations?}

The leaders of the organizations whom we have interviewed define local development in numerous ways. It is conceived as a response to local needs, as the social and economic development of the community, as a process of citizen participation, and as individual empowerment. These conceptions roughly correspond to our definition of local development that covers many aspects of development-not only the economic dimensionand that emphasizes the mobilization of individual and collective local actors. Thus, local development appears to be a way of improving the quality of life locally by offering services specialized in precise fields concerning a diversity of dimensions. These services are defined according to needs detected within the local population and are provided from resources mobilized mainly from the state. It is clear that the community organizations we have studied are conscious of the fact that they have a limited impact on the general social and economic context that affects the local scale. Thus, they participate in bodies of coordination in order to share concerns and address demands to the state. Although limited, the interventions of community organizations prove to be important in several ways.

On one hand, they contribute to the visibility of the diversity and the complexity of the problems and issues at the local scale. The dominant approach used by public authorities is one based on the assumptions of the positive impacts of economic growth. Indicators like the unemployment rate are, of course, used, but the data of economic type, such as the level of income, are finally prevalent in the analysis of the degree of development of a local territory made by public authorities. Through a more detailed analysis that they make of their territory, by listening to the local population, and by their methods of intervention focusing on the participation of individual and collective actors, the community organizations show that there are other dimensions other than the economic one to take into account to support the development of a local territory. Thus, in their effort of mobilizing external financial resources, they attempt to convince the different tiers of government to consider a wider reading of the local reality.

On the other hand, community organizations put forward solidarity and participatory democracy (i.e., a mode of cooperation centered on the 
collective interest and not on the private interest that is embedded in the civil society). The community approach constitutes a mode of intervention different from the one of government and of the private corporations. It also represents a way of creating relationships complementary to the traditional networks.

\section{What Sort of Governance Do These Organizations Contribute to Construct At the Local Level?}

The community organizations we have studied maintain ties with other community organizations in order to share concerns and to have a better understanding of what is at stake, to coordinate action, and to make claims. They also have created linkages with public institutions from the three tiers of government and, to a lesser degree, with private bodies to get resources, to address specifics demands concerning local needs, and to implement projects based on partnership. The collaboration of community organizations with other community organizations and with public and private actors involved in different ways in the process of local development represents a kind of local governance. This sort of governance implies negotiation and compromises between a variety of actors who do not necessarily share the same interests and control the same resources. As we have emphasized earlier, this local governance is primarily local, because the local territory is the object of this governance. However, this governance is also a multilevel one through relationships with public institutions, private bodies, and other community organizations intervening at the inframunicipal, municipal, and supramunicipal levels. Moreover, the community organizations participate in a process of multigovernance, each domain of intervention being the object of the collaboration with specific actors from the community, the public, and the private sectors. For instance, the municipal services, the provincial and the federal agencies with which the employment organizations collaborate are not the same as those with which community centers are linked. Thus, there are several relations of governance in which community organizations participate. But these organizations are not present in urban and metropolitan governances that are essentially concerned with economic issues. This leads us to another question we have raised in the introduction of this article. 


\section{Is There a Link Between the Local Governance in Which Community Organizations Play a Key Role and the Urban and Metropolitan Governances Targeting Economic Growth?}

Community organizations through local governance bring some social change in local territories where poverty is concentrated. However, these changes are pragmatic and contribute mainly to social integration and cohesion. While this approach of development appears to be defensive, the development strategies put forward by public-private partnership in urban and metropolitan governances are offensive. Thus, there is a gap between the community, public, and private actors of local governance, which aim at the improvement of living conditions; and the public and private actors of urban and metropolitan governances, which try to adapt their city and their region to market globalization: a gap between the player in the "little league" of local development and the players of the "major league" of international competitiveness. Community organizations are trapped in this division of responsibilities. Because community organizations do not participate in the debates of the major league, they have a limited access to decisions that make a difference for the population in poverty. Their capacity to obtain a better redistribution of wealth for the people in neighborhoods lacking resources is limited. Implementing coordination between local governance in which community organizations are involved and urban and metropolitan economic governances where they are absent may provide a better articulation between social goals and economic growth, particularly if the actors participating in urban and metropolitan governances accept to deal with local and social problems; but that may not be the case if they only stick to their growth ideology. The current situation indicates that the race for a high level of economic growth preoccupies the political agenda of these actors. Thus, it seems to be important to maintain an active civil society that works in changing the political agenda. This leads to a last question we have raised concerning the links between the community organizations that are at the heart of the civil society and the state.

\section{What Are the Relationships Between Community Organizations and the State, and What Degree of Autonomy Can These Organizations Preserve?}

The public institutions, mainly the provincial ones that give the most important financial support to community organizations, tend to frame their actions; but community organizations also contribute to the orientation of 
the policies of public institutions. Indeed, interviews with individuals working in public agencies reveal that their programs and their way to manage them can be influenced by community organizations. The public institutions, through the contracting relationships they formalized with community organizations, try to channel their action by imposing strategic planning, indicators of success, accountability, and so forth. While bringing this managerial direction to community organizations, public institutions contribute to the establishment of a "community technocracy" or a "community apparatus." Such a tendency is clearly detectable within the community organizations that signed agreements with the government agency in charge of employment in Quebec. In the other domains of intervention, the results of our research indicate the presence of a margin of maneuver and of greater autonomy.

Contract service agreements represent for community organizations a more and more important way of mobilizing resources from the state. But this raises a first level of tension around resources that are allocated and are needed by local organizations. In spite of the fact that community organizations make visible several local problems and receive financial resources to respond to them, it does not mean that they have enough resources to solve these problems. Moreover, the fact of agreeing to work with limited resources creates a second level of tension within community organizations, because they receive just enough resources to mitigate certain negative effects on the population without having the capacity to act on the causes of the problems.

However, the links between community organizations and the state are not limited to the signature of services agreements. The governance in which community organizations are involved is constituted through networks that are not only formal but also informal. These networks-formal and informalare the locus of discussion between individuals representing civil society and the state; and these discussions influence the Quebec political life at the national, regional, municipal, and inframunicipal scales. Do these discussions have the same impact on the political agenda as the private lobbies do? Apparently not, when international competitiveness is at stake.

\section{Notes}

1. Table 1 presents the characteristics of the community organizations that we have studied according to the data of 2001-2002. It is why we present the socioeconomic data of the region of Montreal according to the 2001 census. Moreover, the date of the census of 2006 was not available at the time of our writing. 
2. A district corresponds to a territory that has its own history, identity, and socioeconomic characteristics, without any politico-administrative competence.

3. A borough refers to a geographical and politico-administrative unit that has its own mayor and local councilors as well as some local responsibilities. A borough is formed of two to five districts, depending on the size of these districts.

4. Verdun, which was a municipality, became a borough of Montreal in 2002, after a merging process.

\section{References}

Bauman, Z .1998. Globalization: The human consequences. Cambridge, UK: Polity.

Beck, U. 2000. What is globalization? Cambridge, UK: Polity.

Berry, B. J. L., E. C. Conkling, and M. Ray. 1997. The global economy in transition. 2d ed. Upper Saddle River, NJ: Prentice Hall.

Blakely, E. J., and T. D. Bradshaw. 2002. Planning local economic development: Theory and practice. $3 \mathrm{~d}$ ed. Thousand Oaks, CA: Sage.

Blanc, M. 1998. La transaction, un processus de production et d'apprentissage du «vivre ensemble. In Les transactions aux frontières du social, edited by M.-F. Freynet, M. Blanc, and G. Pineau, 219-37. Lyon, France: Chronique sociale.

Bordie, J. 2002. Citizenship and solidarity: Reflections on the Canadian way. Citizenship Studies 6 (4): 377-94.

Boudreau, J. A. 2003. The politics of territorialization: Regionalism, localism and other isms . . . The case of Montreal. Journal of Urban Affairs 25 (2): 179-99.

Castells, M. 1999. Le pouvoir de l'identité: L'ère de l'information. Paris: Fayard.

Chalmin, P. 1996. Les marchés mondiaux. Paris: Economica.

Chenais, F. 1994. La mondialisation du capital. Paris: Syros.

City of Montreal. 2004. Economic development strategy and action plan for the city of Montreal: Summary (Consultation document). Montreal, Ontario, Canada: Author.

Clavel, P., J. Pitt, and J. Yin. 1997. The community option in urban policy. Urban Affairs Review 32 (4): 435-58.

Communauté Métropolitaine de Montréal. (2004). Charting our international future: A competitive metropolitan Montreal region (Proposed economic development plan). Montreal, Ontario, Canada: Author.

Conférence Régionale des élus de Montréal. 2004. Rapport sur la pauvreté à Montréal. Montréal, Ontario, Canada: Author.

Deslauriers, J.-P. 1985. De l'animation à la révolution. Service Social 34 (2-3): 369-89.

Deslauriers, J.-P., and R. Paquet. 2003. Travailler dans le communautaire. Sainte-Foy, Ontario, Canada: Presses de l'Université du Québec.

Eme, B. 2007. Gouvernance territoriale, puissance publique et société civile. In L'innovation sociale: Émergence et effets sur la transformation des sociétés, edited by J.-L. Klein and D. Harrisson, 153-71. Québec, Ontario, Canada: Presses de l'Université du Québec

Fincher, R., and S. Ruddick. 1983. Transformation possibilities within the capitalist state: Cooperative housing and decentralized health care in Quebec. International Journal of Urban and Regional Research 7:44-71.

Fisher, R., and E. Shragge. 2000. Challenging community organizing: Facing the 21 st century. Journal of Community Practice 8 (3): 1-20. 
Fisher, R., and E. Shragge. 2007. Contextualizing community organizing: Lessons from the past, tensions in the present, opportunities for future. In Transforming the city: Community organizing and the challenge of political change, edited by M. Orr, 193-217. Kansas City: University Press of Kansas.

Friedmann, J. 1998. The new political economy of planning: The rise of civil society. In Cities for citizens, Planning and the rise of civil society in a global age, edited by M. Douglass and J. Friedman, 19-35. Chichester, UK: John Wiley and Son.

Gough, J., A. Eisenschitz, and A. McCulloch. 2006. Spaces of social exclusion. London: Routledge

Hamel, P. 2006. Institutional changes and metropolitan governance: Can de-amalgamation be amalgamation? The case of Montréal. In Metropolitan governing: Canadian cases, comparative lessons, edited by E. Razin and P. J. Smith, 95-120. Jerusalem: Hebrew Univ. Magnes Press.

Hamel, P., H. Lustager-Thaler, and M. Mayer. 2000. Urban social movement-Local thematics, global spaces. In Urban movements in a globalising world, edited by P. Hamel, H. LustagerThaler, and M. Mayer, 1-22. London: Routledge.

Hamel, P., and Jouve, B. 2006. Un modèle québécois? Gouvernance et participation dans la gestion publique. Montreal, Ontario, Canada: Presses de l'Université de Montréal.

Held, D., A. McGrew, D. Goldblatt, and S. Perraton. 1999. Global transformations. Stanford, CA: Stanford Univ. Press.

Ilcan, S., and T. Basok. 2004. Community government: Voluntary agencies, social justice and the responsibilization of citizens. Citizenship Studies 8 (2): 129-44.

Jessop, B. 2001. Institutional re(turns) and the strategic-relational approach. Environment and Planning A, 33: 1213-35.

Jouve, B. 2003. La gouvernance urbaine en question. Collection «Sociologie, Économie, Politique, Territoires». Paris: Elsevier.

Klein, J. L., J. M. Fontan, and D. G. Tremblay. 1999. Question métropolitaine et gouvernance locale: Enjeux et pistes d'intervention à partir du cas montréalais. In Entre la métropolisation et le village global, edited by J.-M Fontan, J.-L. Klein, and D.-G. Tremblay, 9-26. Sainte-Foy, Ontario, Canada: Presses de l'Université du Québec.

Lamoureux, D. 1998. La panacée de l'économie sociale: Un placebo pour les femmes? In L'économie sociale -L'avenir d'une illusion, edited by L. Boivin and M. Fortier, 5-53. Montréal, Ontario, Canada: Fides.

Laval Technopole. 2005. Mission presented on the web site of this body in 2005. http://lavaltechnopole.com/index.php?main_section=home\&section=1\&sub_section=3

Le Galès, P. 1995. Du gouvernement des villes à la gouvernance urbaine. Revue Française des Sciences Politiques 45 (1): 135-70.

Leborgne, D., and A. Lipietz. 1992. Flexibilité offensive, flexibilité défensive. Deux stratégies sociales dans la production de nouveaux espaces économiques. In Les régions qui gagnentDistricts et réseaux: Les nouveaux paradigmes de la géographie économique, edited by $\mathrm{G}$. Benko and A. Lipietz, 347-77. Paris: Presses Universitaires de France.

Longueuil Economic Development. 2005. Mission presented on the web site of this body in 2005. http://www.del.longueuil.ca/www/en/mission.php

McGraw, D. 1978. Le développement des groupes populaires à Montréal (1963-1973). Montreal, Ontario, Canada: Editions Cooperatives Albert Saint-Martin.

Mollenkopf, J., and M. Castells. 1991. Dual city. New York: Russell Sage. 
Morin, R., and J. Hanley. 2004. Community economic development in a context of globalization and metropolization: A comparison of four North American cities. International Journal of Urban and Regional Research 28 (2): 369-83.

Moulaert, F., J.-C. Delvainquière, and P. Delladetsima. 1997. Les rapports sociaux dans le développement local: Le rôle des mouvements sociaux. In Au-delà du libéralisme-Quel rôle pour les mouvements sociaux? edited by J.-L.Klein, P.-A. Tremblay, and H. Dionne, 77-97. Sainte-Foy, Ontario, Canada: Presses de l'Université du Québec.

Organisation for Economic Co-Operation and Development. 1999. Best practices in local development. Paris: LEED Notebook 27. Paris: OCDE.

Panet-Raymond, J., and Mayer, R. 1997. The history of community development in Quebec. In Community organizing: Canadian experiences, edited by B. Wharf and M. Clague, 29-61. Toronto, Ontario, Canada: Oxford Univ. Press.

Parazelli, M., and Tardif, G. 1998. Le mirage démocratique de l'économie sociale. In L'économie sociale l'Avenir d'une illusion, edited by L. Boivin and M. Fortier, 55-99. Montreal, Ontario, Canada: Fides.

Pecqueur, B. 2000. Le développement local. 2d ed. Paris: Syros.

Pierre, J. 1999. Models of urban governance-The institutional dimension of urban politics. Urban Affairs Review 34 (3): 372-96.

Pierre, J. 2005. Comparative urban governance-Uncovering complex causalities. Urban Affairs Review 40 (4): 446-62.

Pierre, J., and B. G. Peters. 2001. Governance, politics and the state. London: Macmillan.

Remy, J. 1998. La transaction sociale. In Les transactions aux frontières du social, edited by M.-F. Freynet, M. Blanc, and G. Pineau, 20-42. Lyon, France: Chronique sociale.

Sancton, A. 2000. Merger mania: The assault on local government. Westmount, Ontario, Canada: Price-Patterson.

Sancton, A. 2001. Canadian cities and the new regionalism. Journal of Urban Affairs 23 (4): 543-55.

Stöhr, W. B. 2003. Development from below: Vingt ans plus tard. In Reconversion économique et développement territorial, edited by J.-M. Fontan, J.-L. Klein, and B. Lévesque, 119-43. Québec, Ontario, Canada: Presses de l'Université du Québec.

Tickell A., and J. A. Peck. 1995. Social regulation after Fordism: regulation theory, neo-liberalism and the global-local nexus. Economy and Society, 24 (3): 357-386.

Vachon, B. 1993. Le développement local-Théorie et pratique-Réintroduire l'humain dans la logique de développement. Boucherville, Ontario, Canada: Gaëtan Morin Éditeur.

White, D. 1997. Contradictory participation: Reflections on community action in Quebec. In Community organizing: Canadian experiences, edited by B. Wharf and M. Clague, 62-90. Toronto, Ontario, Canada: Oxford Univ. Press.

Jean-Marc Fontan is a professor of sociology at the Université du Québec à Montréal. He specializes in the field of socioeconomy, and his research work concerns modalities of development in devitalized areas of metropolitan regions. His recent books address questions linked to local and community development.

Pierre Hamel is a professor of sociology at the Université de Montréal. He has written extensively on social movements, urban politics, and local democracy. He is author and coeditor of several books. 
Richard Morin is a professor in urban studies at the Université du Québec à Montréal. He has conducted researches related to community housing, community development, local development, and regional development. He has authored and coauthored several books and articles, and currently manages the research project associated with this article.

Eric Shragge teaches at the School of Community and Public Affairs at Concordia University in Montreal. His areas of interest include community organizing and issues related to the rights of immigrant workers. He is author and coeditor of several books. 